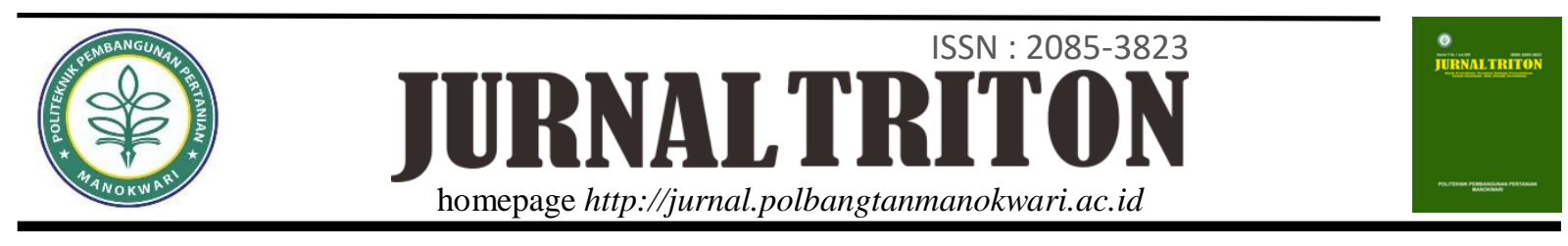

\title{
Efektivitas Metode Penyuluhan dalam Desiminasi Budidaya Bawang Putih Ramah Lingkungan di Kabupaten Karanganyar
}

\section{Tri Cahyo Mardiyanto ${ }^{*}$, Samijan ${ }^{2}$, Ridha Nurlaily ${ }^{3}$}

${ }^{1,2,3}$ Balai Pengkajian Teknologi Pertanian Jawa Tengah

\section{ARTIKEL INFO}

Sejarah artikel

Diterima 15/06/2020

Diterima dalam bentuk revisi 25/06/2020

Diterima dan disetujui 26/06/2020

Tersedia online 30/06/2020

Kata kunci :

Demplot

Diseminasi

Efektivitas

Pelatihan

Temu lapang

\section{ABSTRAK}

Bawang putih (Allium sativum L) selain merupakan salah satu jenis sayuran penting di dataran tinggi, sekaligus merupakan salah satu sumber pertumbuhan baru ekonomi dalam pembangunan pertanian. Penelitian bertujuan untuk menganalisis faktor-faktor yang mempengaruhi efektivitas diseminasi teknologi budidaya bawang putih ramah lingkungan melalui pelatihan, demplot, dan temu lapang pada petani di Pancot, Desa Kalisoro, Kecamatan Tawangmangu, Kabupaten Karanganyar. Penelitian menggunakan pendekatan kuantitatif. Populasi penelitian adalah anggota kelompok taruna tani Tani Maju yang tergabung dalam Gabungan Kelompok Tani Ngudi Rejeki. Responden penelitian ditetapkan sebanyak 40 orang taruna tani. Data yang dikumpulkan meliputi persepsi petani terhadap pelaksanaan diseminasi, dan tingkat efektivitas diseminasi, meliputi pelatihan, demplot, dan temu lapang, terhadap teknologi rekomendasi. Data dianalisis mengunakan teknik analisis statistik deskriptif dan analisis jalur. Hasil penelitian menunjukkan terdapat 27 petani yang menilai bahwa pelaksanaan diseminasi efektif dengan nilai 90\%. Ketiga metode diseminasi, yaitu pelatihan, demplot, dan temu lapang secara signifikan berpengaruh terhadap efektivitas diseminasi, dengan besar pengaruh masing - masing adalah 79,92\%, $26,21 \%$, dan $45,02 \%$. Besar pengaruh pelatihan, demplot, dan temu lapang secara bersama-sama terhadap efektivitas desiminasi adalah $89,5 \%$ sedangkan sisanya yaitu $10,49 \%$ dipengaruh oleh faktor atau variabel lain di luar ketiga metode tersebut.

(C) 2020 Politeknik Pembangunan Pertanian Manokwari 


\section{ABSTRACT}

Garlic (Allium sativum L), besides being one of the important types of vegetables in the highlands, is at the same time a source of new economic growth in agricultural development. The research aims to analyze the factors that influence the effectiveness of the dissemination of environmentally friendly garlic cultivation technology through training, demonstration plots, and field meetings among farmers in Pancot, Kalisoro Village, Tawangmangu District, Karanganyar Regency. Research uses a quantitative approach. The study population is a member of the youth farmer group namely Tani Maju which is incorporated in the Ngudi Rejeki Farmers Group Association. The respondents were determined as many as 40 youth farmers. Data collected included farmers' perceptions of the implementation of dissemination, and the

\section{PENDAHULUAN}

Keberhasilan kegiatan pelaksanaan tugas Balai Pengkajian Teknologi Pertanian Jawa Tengah ditentukan oleh tingkat pemanfaatan dan penerapan inovasi yang dihasilkannya oleh masyarakat tani di wilayahnya. Agar hasil pengkajian dari BPTP dapat dimanfaatkan oleh pengguna akhir (masyarakat tani/pelaku agribisnis lainnya) dan pengguna antara, maka diperlukan upaya penyebar luasan inovasi teknologi yang dimiliki BPTP melalui mekanisme dan metode yang tepat. Dalam pelaksanaannya di lapangan, kegiatan penyebar luasan inovasi teknologi tidak terpisah atau berdiri sendiri, melainkan merupakan bagian yang tidak terpisahkan dari program pengkajian.

Untuk mengetahui daya dan hasil guna (melalui kegiatan deseminasi) inovasi teknologi budidaya bawang putih ramah lingkungan, telah diintroduksikan dan disosialisasikan kepada petani, maka perlu dilakukan kajian preferensi petani terhadap effectiveness of dissemination, including training, demonstration plots, and field meetings, on technology recommendations. Data were analyzed using descriptive statistical analysis techniques and path analysis. The results showed that there were 27 farmers who rated the dissemination to be effective with a value of $90 \%$. The three methods of dissemination, namely training, demonstration plots, and field meetings significantly influence the effectiveness of dissemination, with the magnitude of each effect being 79.92\%, 26.21\%, and $45.02 \%$. The influence of training, demonstration plots and field meetings jointly on the effectiveness of dissemination was $89.5 \%$, while the remaining $10.49 \%$ was influenced by factors or other variables outside the three methods.

inovasi teknologiyang diintroduksikan. Dari hasil kajian tersebut diharapkan dapat diketahui persepsi petani dan pengaruh (melalui) metode penyuluhan pelatihan, demplot, serta temu lapang terhadap efektivitas diseminasi teknologi budidaya bawang putih ramah lingkungan. Dengan demikian, apabila terdapat beberapa kelemahan dalam proses introduksi inovasi dan atau dalam implemenntasi di lapangan dapat segera diketahui untuk dicari solusinya agar dapat dijadikan bahan masukan untuk pelaksanaan implementasi tahun selanjutnya.

Bawang putih (Allium sativum L) selain merupakan salah satu jenis sayuran penting di dataran tinggi, sekaligus merupakan salah satu sumber pertumbuhan baru ekonomi dalam pembangunan pertanian. Bawang putih ini dianggap sebagai komoditas potensial terutama untuk subsitusi impor dan dalam hubungannya dengan penghematan devisa. Sementara ini Peningkatan produksi dan produktivitas bawang putih nasional dihadapkan pada masalah kelangkaan benih bermutu. Untuk 
mendapatkan benih berdaya hasil tinggi semakin sulit, banyak petani menggunakan benih umbi dari bawang konsumsi. Disisi lain usaha untuk mendapatkan benih umbi berdaya hasil tinggi untuk bawang putih memerlukan waktu yang panjang karena petani harus melakukan melalui proses pemurnian benih, sementara kebutuhan terhadap varietas yang berdaya hasil tinggi semakin mendesak.

Untuk mengetahui faktor-faktor yang mempengaruhi efektivitas diseminasi teknologi budidaya bawang putih ramah lingkungan, yang telah diintroduksikan dan disosialisasikan kepada petani melalui persepsi dan pengaruh pelatihan, demplot, dan temu lapang terhadap diseminasi teknologi budidaya bawang putih ramah lingkungan. Untuk perlu dilakukan analisa dari data yang diperoleh, sehingga tujuan analisa ini adalah :

1. Menjelaskan persepsi petani terhadap diseminasi teknologi bawang putih ramah lingkungan.

2. Menjelaskan besarnya pengaruh langsung pelatihan terhadap diseminasi teknologi bawang putih ramah lingkungan.

3. Menjelaskan besarnya pengaruh langsung demplot terhadap diseminasi teknologi bawang putih ramah lingkungan.

4. Menjelaskan besarnya pengaruh langsung temu lapang terhadap diseminasi teknologi bawang putih ramah lingkungan.

5. Menjelaskan besarnya pengaruhsecara bersama-sama pelatihan, demplot, dan temu lapang terhadap diseminasi teknologi bawang putih ramah lingkungan

\section{METODE}

Data yang dianalisa merupakan data primer yang diperoleh dari kegiatan Diseminasi pada tanggal 26 September 2015 dengan jumlah resonden 40 orang. Penilaian ini diambil dari kegiatan pengkajian/peragaan penerapan teknologi budidaya bawang putih ramah lingkungan dilaksanakan oleh 6 orang petani kooperator yang tergabung dalam Kelompok Taruna Tani "Tani Maju" dan tergabung dalam Gapoktan "Ngudi Rejeki" di Lingkungan Pancot, Desa Kalisoro, Kecamatan Tawangmangu pada bulan Mei sampai September 2015. Lahan yang digunakan seluas $3.000 \mathrm{~m}^{2}$. Data yang diperoleh kemudian dilakukan analisa di Kantor BPTP Jawa Tengah pada tanggal 2 November 2015.

Data yang digunakan dalam analisa ini adalah data primer. Data primer diperoleh dengan cara wawancara langsung, ataupun observasi dengan responden berdasarkan daftar pertanyaan yang telah disiapkan. Wawancara, yaitu pengumpulan data dengan mengajukan pertanyaan secara langsung kepada responden dengan menggunakan kuesioner sebagai panduannya. Hasil kuisioner ini akan diolah dalam bentuk angka-angka, analisis statistik, dan uraian serta kesimpulan hasil analisa (Singarimbun 1995).

Desain analisa statistik yang dilakukan menggunakan analisa statistik desktriptif yaitu untuk mendeskriptifkan atau memberikan gambaran terhadap objek yang akan dianalisa (Sugiyono, 2006). Menurut Mardikanto (2010), statistik deskriptif adalah bagian ilmu statistik yang bertujuan untuk mempelajari tata 
cara pengumpulan data, pencatatan, penyusunan/penyajian data dalam bentuk tabel frekuensi atau grafik, untuk selanjutnya dilakukan pengukuran nilai-nilai statistiknya.

\section{Analisa Deskripsi Kuantitatif}

Data analisa ini meliputi presepsi petani terhadap pelaksanaan diseminasi dengan melihat : (i). tingkat kepercayaan petani terhadap manfaat yang diperoleh dari diseminasi untuk petani, masyarakat, dan lingkungan sekitar; (ii). Tingkat keberhasilan pelaksanaan diseminasi dalam penyampaian/menyebarluaskan teknologi budidaya bawang putih ramah lingkungan; (iii). Tingkat penerapatan petani teknbologi rekomendasi pada musim selanjutnya; (iv). Intensitas penerapan petani terhadap komponen teknologi budidaya bawang putih ramah lingkungan; (v). Tingkat kepuaasan petani terhadap penerapan teknologi rekomendasi; (vi). Tingkat kepuasan petani terhadap pelaksanaan pendampingan; (vii). Tingkat pemahaman petani terhadap komponen teknbologi; (viii). Tingkat pemahaman petani mengenai tuntutan pasar yang menghendaki produk yang aman untuk dikonsumsi; (ix). Tingkat efektivitas diseminasi terhadap pengenalan teknoloogi rekomendasi; dan (x). Tingkat efektivitas diseminasi dalam penerapan teknologo rekomendasi.

Menurut Mardikanto (2010), upaya penyajian ini dimaksudkan mengungkapkan informasi penting yang terdapat dalam data kedalam bentuk yang lebih ringkas dan sederhana yang pada akhirnya mengarah pada keperluan adanya penjelasan dan penafsiran.
Analisis statistik deskriptif dilaksanakan melalui beberapa tahapan :

a. Penyajian data analisa dengan metode tabulasi;

b. Penentuan kecenderungan nilai responden untuk masing-masing variabel yang dikelompokkan ke dalam 3 (tiga) kelas kriteria masing-masing adalah : rendah, sedang, dan tinggi. Interval kelas ditentukan dengan rumus sebagai berikut:

Interval Kelas $=\frac{\text { Nilai Tertinggi }- \text { Nilai Terendah }}{\text { Klasifikasi }}$

Untuk melihat keefektifan setiap metode terhadap pengetahuan, sikap dan respon peserta digunakan klasifikasi yang dikategorikan menjadi 3 kategori : (1) rendah, (2) sedang, (3) tinggi. Interval klasifikasi dicari dengan formula (Awat, 1995):

$\mathrm{I}=\mathrm{J} / \mathrm{K}$

$\mathrm{I}=$ Interval kelas

$\mathbf{J}=$ Jarak (nilai terbesar dikurangi nilai terkecil)

$\mathrm{K}=$ Banyaknya kelas yang digunakan

Berdasarkan formula di atas maka interval kelas :

$$
I=(3-1) / 3=0,66
$$

Interval kategori jawaban sebagai berikut:

Skor antara 2,34-3,00 : kategori tinggi

Skor antara 1,67-2,33 : ketegori sedang

Skor antara $1-1,66$ : kategori rendah 


\section{Analisa Jalur (Path Analysis)}

Tingkat keefektifan atau efektivitas sosialisasi adopsi inovasi budidaya bawang putih ramah lingkungan kepada pengguna dilihat dari ketiga metode peyuluhan yaitu : Pelatihan, Demplot dan Temu lapang. Menurut Slamet (2001) efektivitas kelompok ekuivalen dengan keberhasilan kelompok yang cenderung meningkatkan dinamika kelompok yang dapat dilihat dilihat dari sudut: (1) hasil/produktivitasnya dalam mencapai tujuan; (2) moral kelompok dengan melihat semangat kerjasama dan kesungguhan; dan (3) tingkat kepuasan anggota-anggotanya. Tingkat efektivitas kegiatan ini akan diukur dengan melihat hasil yang dicapai, kesungguhan (sikap, pengetahuan, dan keterampilan) peserta, dan tingkat kepuasan peserta masingmasing kelompok. Pengukurannya dengan menggunakan analisis jalur (path analysis) untuk mengetahui seberapa jauh pengaruh ketiga kegiatan terhadap tingkat efektifitas sosialisasi adopsi inovasi budidaya bawang putih ramah lingkungan.

Analisis jalur merupakan salah satu analisis induktif/inferensial yang bertugas mempelajari tata cara penarikan kesimpulan mengenai keseluruhan populasi berdasarkan data hasil penelitian pada sampel/contoh yang diamati (Mardikanto 2010). Data hasil penelitian ini dianalisis menggunakan analisis jalur untuk menjawab hipotesis (Sudjana 2003). Berikut ini adalah diagram analisis jalur variabel Pelatihan (XP), Demplot (XD), Temu Lapang (XT), dan Tingkat Efektivitas Kegiatan Sosialisasi (Y). Diagram analisis jalur dapat dilihat pada Gambar 1.

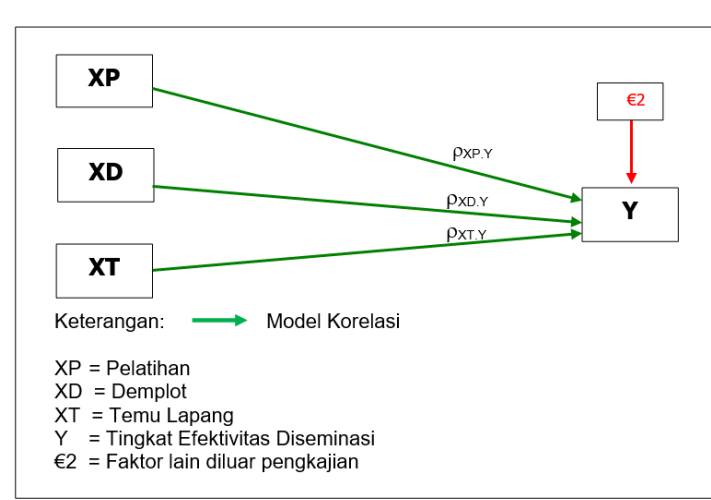

Gambar 1. Diagram Analisis Jalur

Beberapa tahapan analisis jalur pada penelitian ini adalah sebagai berikut:

a. Menghitung koefisien determinasi (R2) dan uji signifikansinya

$$
\text { Koefisien determinasi }
$$
menunjukkan pengaruh gabungan beberapa variabel bebas terhadap variabel terikat. Pada penelitian ini terdapat 1 (satu) model analisis jalur, oleh karenanya diperoleh koefisien determinasi (R2). Untuk mengetahui apakah besarnya nilai R2 dapat diterima secara statistik, dilakukan pengujian linearitas melalui uji F. Pengujian linearitas dilakukan menggunakan program SPSS yang menghasilkan nilai Fhitung dan nilai sign. Pengujian dilakukan pada taraf nyata 5\% $(\alpha=$ $0,05)$ dengan kriteria pengujian:

- H1 diterima atau terdapat hubungan linier jika nilai sign $<\alpha$

- H1 ditolak atau tidak terdapat hubungan linier jika nilai sign $>\alpha$

Menghitung besarnya koefisien jalur ( $\square$ ) antar variabel dan uji signifikansinya. Besarnya koefisien jalur ( $\square$ ) dihitung menggunakan program SPSS dan pengujian dilakukan melalui uji t. Hipotesis yang diuji adalah sebagai berikut: H1 : $\square>0$; H0 : $\square=$ 0 . Pengujian dilakukan dengan statistik uji $t$ 
menggunakan program SPSS yang menghasilkan nilai $\square$, thitung dan nilai sign. Pengujian dilakukan pada taraf nyata 5\% $(\alpha=$ $0,05)$ dengan kriteria pengujian:

- H1 diterima jika nilai sign $<\alpha$

- H1 ditolak jika nilai sign $>\alpha$

b. Menghitung koefisien korelasi (r) antar variabel dan signifikansinya.

Koefisien korelasi (r) menunjukkan besarnya hubungan antar variabel. Besarnya nilai $r$ pada penelitian ini dihitung menggunakan program SPSS 17. Hipotesis yang diuji adalah sebagai berikut:

H1 : Terdapat korelasi antar variabel

H0 : Tidak terdapat korelasi antar variabel

$\mathrm{H} 1: \mathrm{r} \neq 0, \quad \mathrm{H} 0: \quad \mathrm{r}=0$

Pengujian dilakukan dengan statistik menggunakan program SPSS yang menghasilkan nilai $r$ dan nilai sign. Pengujian dilakukan pada taraf nyata $5 \% \quad(\alpha=0,05)$ dengan kriteria pengujian:

- H1 diterima jika nilai sign $<\alpha$

- H1 ditolak jika nilai sign $>\alpha$

c. Menentukan pengaruh langsung dan pengaruh tidak langsung antar variabel.

Sudjana (2003) menyatakan bahwa untuk menentukan besarnya pengaruh langsung dan pengaruh tidak langsung didasarkan pada keterkaitan koefisien korelasi (r) dan koefisien jalur ( $\square$ ). Pengujian terhadap seberapa jauh kuatnya pengaruh langsung dibanding dengan pengaruh tak langsung, dihitung dengan membandingkan antara besarnya nilai $\beta$ dengan $r-\beta$.

- Jika $\beta>(r-\beta)$, maka variabel bebas benarbenar memiliki pengaruh langsung terhadap variabel tergantungnya.
- $\quad$ Jika $\beta<(r-\beta)$, maka variabel-bebas tidak memiliki pengaruh langsung terhadap variabel tergantung, dan pengaruhnya lebih ditentukan oleh pengaruh variabel lainnya terhadap variabel tergantungnya.

\section{HASIL DAN PEMBAHASAN}

Inovasi teknologi budidaya bawang putih ramah lingkungan diperkenalkan kepada pengguna (petani dan petugas pertanian) pada Kegiatan Diseminasi Budidaya Bawang Putih Ramah Lingkungan di Kabupaten Karanganyar pada bulan Mei s/d September 2015 di Lingkungan Pancot, Kalurahan Kalisoro, Kecamatan Tawangmangu, Kabupaten Karanganyar. Keragaan varietas yang didiseminasikan adalah varietas Tawangmangu Baru dan Lumbu Hijau dengan perlakuan pemupukan spesifik lokasi dan ramah lingkungan diharapkan dapat diterapkan oleh petani sebagai teknologi budidaya rekomendasi.

Suatu inovasi teknologi (dalam hal ini teknologi budidaya bawang putih ramah lingkungan) yang disukai oleh seseorang akan membentuk respon positif bagi seseorang tersebut. Respon positif sebagai penilaian dari persepsi pengguna, akan mengkristal sebagai potensi reaksi atau kecenderungan untuk bersikap positif, selanjutnya diharapkan berakhir dengan diadopsinya inovasi teknologi (budidaya bawang putih ramah lingkungan) yang dijelaskan kepada prospek pengembangannya (Mardikanto, 2010). Tingkat persepsi petani inilah yang akan menjadi variabel dalam menentukan efektivitas kegiatan diseminasi. Untuk mengetahui 
seberapa besar pengaruh dari ketiga metode penyuluhan diseminasi melalui pelatihan, demplot, dan temu lapang, maka dilakukan uji pengaruh dengan metode analisa jalur.

\section{Uji Normalitas}

Data yang telah diperoleh dari pengkajian, sebelum dilakukan analisa jalur (path analysis) dilakukan terlebih dahulu uji normalitas yaitu untuk mengetahui distribusi (sebaran) skor yang diamati yang diukur dengan skala ordinal (Mardikanto, 2010). Pada pengkajian ini, uji normalitas ini dilakukan terhadap data variabel pelatihan, demplot, temu lapang, dan efektivitas diseminasi. Dari uji normalitas diperoleh hasil bahwa semua variabel tersebut mempunyai distribusi normal. Hal ini dapat dilihat bahwa semua nilai Kolmogorof Smirnof dimana sign $<\alpha$. Hasil perhitungan dan keputusannya dapat dilihat pada Tabel 1.

Tabel 1. Hasil Perhitungan Uji Normalitas

\begin{tabular}{|c|l|c|c|c|c|}
\hline No & \multicolumn{1}{|c|}{ Variabel } & $\begin{array}{c}\text { Kolmogorof } \\
\text { Smirnof }\end{array}$ & Sign & $\boldsymbol{\alpha}$ & Keputusan \\
\hline 1 & Pelatihan & 0,430 & 0,000 & 0,05 & Distribusi Normal \\
\hline 2 & Demplot & 0,303 & 0,000 & 0,05 & Distribusi Normal \\
\hline 3 & Temu Lapang & 0,241 & 0,000 & 0,05 & Distribusi Normal \\
\hline 4 & Efektivitas Diseminasi & 0,470 & 0,000 & 0,05 & Distribusi Normal \\
\hline
\end{tabular}

\section{Analisis Jalur (Path Analysis)}

Menurut Riduwan (2008), analisis jalur digunakan untuk menganalisis pola hubungan antar variabel dengan tujuan untuk mengetahui pengaruh langsung maupun tidak langsung seperangkat variabel bebas (eksogen) terhadap variabel terikat (endogen). Menurut Mardikanto (2010), menyebutkan bahwa dalam analisas jalur akan menguji kesignifikansian pengaruh dari variabelvariabel bebas terhadap variabel terikatnya yang ditunjukkan pada koefisien jalur sesuai dengan alur hubungan variabel yang dibangun dalam penelitian, oleh karena itu analisas jalur tidak memerlukan uji autokorelasi, multikolinierity (uji linearitas), maupun heteroscedastic (uji homogenitas).

Uji dilakukan dengan menggunakan SPSS 17 untuk menganalisis pengaruh pelatihan, demplot, dan temu lapang terhadap efektivitas diseminasi. Data ordinal yang akan dianali sa terlebih dahulu ditransformasikan menjadi data interval. Proses tranformasi data ini agar menjadi nilainya menjadi standar menggunakan program SPSS 17 yang hasil transfomrasinya sama dengan rumus yang digunakan Richard A Johnson, et al. (2002) yaitu sebagai berikut:

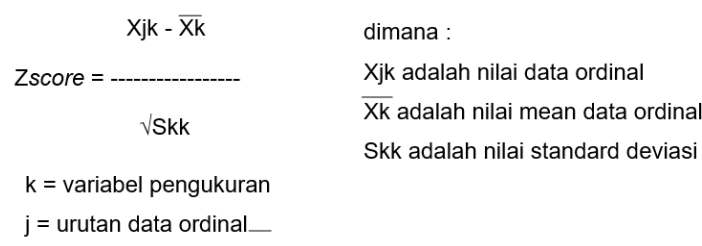

\section{Persepsi Petani terhadap Pelaksanaan}

Diseminasi Teknologi Budidaya Bawang Putih Ramah Lingkungan

Pada analisa deskriptif terhadap evaluasi pelaksanaan desiminasi dilakukan penilaian persepsi oleh petani bawang putih di Kecamatan Tawangmangu. Penilaian tersebut meliputi : (i). Tingkat kepercayaan petani bahwa teknologi indovasi yang disampaikan 
memiliki manfaat bagi petani, masyarakat sekitar dan lingkungan; (ii). Tingkat keberhasilan pelaksanaan diseminasi dalam menyebarluaskan inovasi tenologi; (iii). Tingkat penerapan inovasi teknologi oleh petani pada musim tanam berikutnya; (iv). Intensitas penerapan komponen inovasi teknologi oleh petani pada musim tanam berikutnya; (v). Tingkat kepuasan petani terhadap penerapan inovasi teknologi; (vi). Tingkat kepuasan petani mengenai pendampingan dalam pelaksanaan diseminasi; (vii). Tingkat pemahaman petani terhadap komponen inovasi teknologi; (viii). Tingkat pemahaman petani mengenai tuntutan pasar global yang menghendaki produk yang aman untuk dikonsumsi; (ix). Tingkat keefektivan diseminasi dalam mengenalkan inovasi teknologi; dan (x). Tingkat keefktivan diseminasi dalam menerapkan inovasi teknologi. Penilaian atau persepsi petani terhadap pelaksanaan diseminasi dapat dilihat pada Tabel 2.

Dari Tabel 2 dapat dilihat bahwa dari semua pertanyaan yang diajukan untuk mengetahui efektivitas pelaksanaan diseminasi semua petani menilai pada kategori tinggi, hal ini menjelaskan bahwa pelaksanaan diseminasi dapat dikatakan efektif dalam menyebarluaskan teknologi budidaya bawang putih ramah lingkungan di Kabupaten Karanganyar. Hal ini diperkuat dengan penilaian petani secara keseluruhan, yaitu 27 petani menilai pada kategori tinggi yaitu $90 \%$.

Tabel 2. Persepsi petani terhadap pelaksanaan diseminasi teknologi budidaya bawang putih ramah lingkungan

\begin{tabular}{|c|c|c|c|c|}
\hline No & Komponen Teknologi & Interval Skor & $\begin{array}{l}\text { Petani } \\
\text { (Orang) }\end{array}$ & $\%$ \\
\hline \multirow[t]{3}{*}{1} & \multirow{3}{*}{$\begin{array}{l}\text { Tingkat kepercayaan petani bahwa teknologi } \\
\text { indovasi yang disampai-kan memiliki manfaat } \\
\text { bagi petani, masyarakat sekitar dan lingkungan }\end{array}$} & $1-1,67$ & 0 & 0 \\
\hline & & $1,68-2,35$ & 11 & 27,5 \\
\hline & & $2,36-3$ & 29 & 72.5 \\
\hline \multirow[t]{3}{*}{2} & \multirow{3}{*}{$\begin{array}{l}\text { Tingkat keberhasilan pelaksanaan diseminasi } \\
\text { dalam menyebarluas-kan inovasi tenologi }\end{array}$} & $1-1,67$ & 0 & 0 \\
\hline & & $1,68-2,35$ & 14 & 35 \\
\hline & & $2,36-3$ & 26 & 65 \\
\hline \multirow[t]{3}{*}{3} & \multirow{3}{*}{$\begin{array}{l}\text { Tingkat penerapan inovasi teknologi oleh } \\
\text { petani pada musim tanam berikutnya }\end{array}$} & $1-1,67$ & 0 & 0 \\
\hline & & $1,68-2,35$ & 10 & 25 \\
\hline & & $2,36-3$ & 30 & 75 \\
\hline \multirow[t]{3}{*}{4} & \multirow{3}{*}{$\begin{array}{l}\text { Intensitas penerapan } \\
\text { teknologi oleh petani pada musim tanam } \\
\text { berikutnya }\end{array}$} & $1-1,67$ & 0 & 0 \\
\hline & & $1,68-2,35$ & 11 & 27,5 \\
\hline & & $2,36-3$ & 29 & 72,5 \\
\hline \multirow[t]{3}{*}{5} & \multirow{3}{*}{$\begin{array}{l}\text { Tingkat kepuasan petani terhadap penerapan } \\
\text { inovasi teknologi }\end{array}$} & $1-1,67$ & 0 & 0 \\
\hline & & $1,68-2,35$ & 11 & 27,5 \\
\hline & & $2,36-3$ & 29 & 72,5 \\
\hline No & Komponen Teknologi & Interval Skor & $\begin{array}{l}\sum_{\text {(Orang) }} \text { Petani } \\
\text { (Orang }\end{array}$ & $\%$ \\
\hline \multirow[t]{3}{*}{6} & \multirow{3}{*}{ 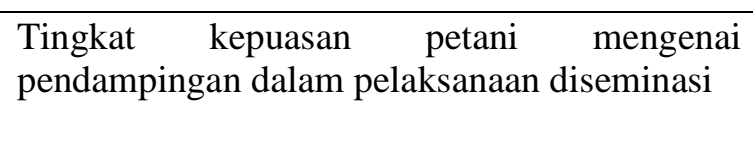 } & $1-1,67$ & 0 & 0 \\
\hline & & $1,68-2,35$ & 10 & 25 \\
\hline & & $2,36-3$ & 30 & 75 \\
\hline \multirow[t]{3}{*}{7} & \multirow{3}{*}{$\begin{array}{l}\text { Tingkat pemahaman petani terhadap } \\
\text { komponen inovasi teknologi }\end{array}$} & $1-1,67$ & 0 & 0 \\
\hline & & $1,68-2,35$ & 11 & 27,5 \\
\hline & & $2,36-3$ & 26 & 72,5 \\
\hline
\end{tabular}




\begin{tabular}{|c|l|c|c|c|}
\hline 8 & Tingkat pemahaman petani mengenai tuntutan & $1-1,67$ & 0 & 0 \\
\cline { 3 - 4 } & pasar global yang menghendaki produk yang & $1,68-2,35$ & 8 & 20 \\
\cline { 3 - 4 } & aman untuk dikonsumsi & $2,36-3$ & 32 & 80 \\
\hline 9 & Tingkat keefektivan diseminasi dalam & $1-1,67$ & 0 & 0 \\
\cline { 3 - 5 } & mengenalkan inovasi teknologi & $1,68-2,35$ & 8 & 20 \\
\cline { 3 - 5 } & & $2,36-3$ & 32 & 80 \\
\hline 10 & Tingkat keefktivan diseminasi dalam & $1-1,67$ & 0 & 0 \\
\cline { 3 - 5 } & menerapkan inovasi teknologi & $1,68-2,35$ & 10 & 25 \\
\hline & & $2,36-3$ & 30 & 75 \\
\hline 11 & Keseluruhan & $10-16,67$ & 0 & 0 \\
\cline { 3 - 5 } & & $16,68-23,35$ & 8 & 20 \\
\hline
\end{tabular}

Analisa Pengaruh Pelatihan, Demplot, dan

Temu Lapang terhadap Efektivitas

Diseminasi Teknologi Budidaya Bawang

Putih Ramah Lingkungan

Untuk mengetahui besaran pengaruh dari ketiga metode penyuluhan yaitu pelatihan, demplot, dan temu lapang dilakukan analisa jalur terhadap efektivitas deseminasi teknologi budidaya bawang putih ramah lingkungan di Kabupaten karanganyar. Untuk itu dilakukan uji pengaruh dari gabuangan ketiga metode tersebut dan uji pengaruh dari masing-masing metode terhadap efektivitas diseminasi.

\section{Analisis Pengaruh Gabungan}

Variabel Pelatihan (XP), Demplot (XD), dan

Temu Lapang (XT), terhadap Efektivitas

Diseminasi (Y)

Untuk melihat pengaruh gabungan Pelatihan (XP), Demplot (XD), dan Temu Lapang (XT) terhadap Efektivitas Diseminasi (Y) dapat dilihat dari koefisien determinasi (R). Berdasarkan perhitungan menggunakan SPSS diperoleh hasil sebagai berikut:

Tabel 3. Hasil Uji Pengaruh Pelatihan (XP), Demplot (XD), dan Temu Lapang (XT) terhadap Efektivitas Diseminasi (Y)

\begin{tabular}{|c|c|c|c|c|}
\hline Uraian & $\mathrm{R}^{2}$ & F Hitung & Sign & $\alpha$ \\
\hline Persamaan & 0,895 & 34,864 & 0,000 & 0,05 \\
\hline
\end{tabular}

Berdasarkan Tabel 3, maka besarnya pengaruh secara bersama variabel pelatihan, demplot, dan temu lapang terhadap efektivitas diseminasi dapat dilihat dari koefisien determinasi (RYXPXDXT) adalah sebesar $0,895=89,5 \%$. Sehingga residu $\dot{\rho} \mathrm{Y} € 2=\sqrt{ } 1$ $-\mathrm{R} 2=\sqrt{ } 1-0,895=0,324$. Hal ini berarti bahwa pengaruh variabel $\mathrm{Y}$ yang tidak dapat dijelaskan atau di luar variabel yang dianalisa adalah $(0,324) 2=0,1049=10,49 \%$. Dari data analisa menujukkan bahwa pelatihan, demplot, dan temu lapang secara bersama-sama memiliki pengaruh langsung terhadap efektivitas diseminasi adalah sebesar 89,5\% sedangkan sisanya yaitu $10,49 \%$ dipengaruhi oleh faktor lain.

2. Analisis Pengaruh Parsial dari masing-masing Variabel Pelatihan (XP), Demplot (XD), dan Temu Lapang (XT) terhadap Efektivitas Diseminasi (Y). 
Untuk melihat pengaruh parsial/secara individu variabel pelatihan (XP), demplot (XD), dan temu lapang (XT) terhadap efektivitas diseminasi (Y) dapat dilihat dari nilai coefficients yang tersaji pada Tabel 4.

Tabel 4. Nilai Koefisien Jalur Pelatihan (XP), Demplot (XD), dan Temu Lapang (XT) terhadap Efektivitas Diseminasi (Y)

\begin{tabular}{|c|c|c|c|c|c|}
\hline Uraian & $\beta$ & t hitung & Sign & $\alpha$ & Keputusan \\
\hline$\dot{\rho}_{\text {YXP }}$ & 0,894 & 10,583 & 0,000 & 0,05 & $\mathrm{H}_{1}$ diterima \\
\hline$\dot{\rho}_{\text {YXD }}$ & 0,512 & 3.156 & 0,004 & 0,05 & $\mathrm{H}_{1}$ diterima \\
\hline$\dot{\rho}_{\text {YXT }}$ & 0,671 & 4,786 & 0,000 & 0,05 & $\mathrm{H}_{1}$ diterima \\
\hline
\end{tabular}

Berdasarkan Tabel 4, menujukkan bahwa ketiga variabel (pelatihan, demplot, dan temu lapang) memiliki pengaruh yang signifikan terhadap efektivitas diseminasi dengan ditunjukkan bahwa H1 diterima, artinya masing-masing variabel berpengaruh secara signifikan terhadap efektivitas diseminasi. Besar pengaruh dari masing masing variabel tersebut adalah sebagai berikut

1. Variabel pelatihan (XP) memiliki koefisien jalur (’’YXP) terhadap efektivitas diseminasi (Y) sebesar 0,894. Hal ini berarti bahwa besar pengaruh XP terhadap $\mathrm{Y}$ adalah $79,92 \%(0,8942 \times 100 \%)$.

2. Variabel demplot (XD) memiliki koefisien jalur (’’YXD) terhadap efektivitas diseminasi (Y) sebesar 0,512. Hal ini berarti bahwa besar pengaruh XD terhadap Y adalah $26,21 \%(0,5122 \times 100 \%)$.

3. Variabel temu lapang (XT) memiliki koefisien jalur (’’YXT) terhadap efektivitas diseminasi (Y) sebesar 0,671. Hal ini berarti bahwa besar pengaruh XD terhadap $\mathrm{Y}$ adalah $45,02 \% \quad(0,6712 \mathrm{x}$ $100 \%)$.

Sehingga persamaan struktural berdasarkan hasil koefisien jalur yaitu:
Persamaan :

$$
\begin{aligned}
& \mathrm{Y}=\dot{\rho} \mathrm{YXPXP}+\dot{\rho} \mathrm{YXDXD}+\dot{\rho} \mathrm{YXTXT}+ \\
& =0,894 \mathrm{XP}+0,512 \mathrm{XD}+0,671 \mathrm{XT}+ \\
& 0,324 € 1 \text { dan R2YXTXDXP }=0,985
\end{aligned}
$$

Berdasarkan hasil analisis data pengkajian yang telah disajikan pada sub bab sebelumnya, maka analisis jalur dapat digambarkan sebagai berikut :

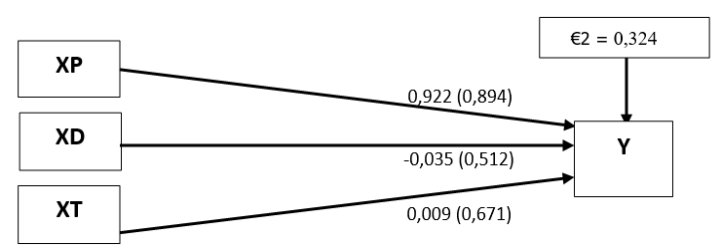

Gambar 2. Model Analisa Pelatihan (XP),

Demplot (XD), dan Temu Lapang (XT) terhadap Effektivitas Diseminasi (Y) Berdasarkan informasi tersebut disimpulkan bahwa variabel pelatihan mempunyai pengaruh langsung lebih besar terhadap efektivitas diseminasi, jika bandingkan dengan pengaruh langsung demplot dan temu lapang. Hal ini menunjukkan semakin meningkatnya dukungan pelatihan maka kecenderungan efektivitas diseminasi akan meningkat.

Variabel pelatihan memiliki pengaruh lebih besar yaitu 79,92\% dari variabel lainnya (demplot dan temu lapang) dikarenakan dalam 
pelaksanaan pelatihan melibatkan semua petani bawang putih di Kecamatan Tawangmangu, sehingga inovasi teknologi dapat tersampaikan ke semua petani bawang putih karena dalam skala luas yaitu tingkat kecamatan. Berbeda dengan variabel demplot, yaitu dalam pelaksanaannya hanya melibatkan beberapa petani bawang putih yaitu 6 (enam) petani sebagai petani kooperator, sehingga pada waktu pengambilan data yang merupakan penilaian (judgment) semua petani bawang putih dinilai kurang memberikan pengaruh yang besar terhadap efektivitas diseminasi, hal ini terlihat pada besar pengaruh variabel demplot terhadap efektivitas diseminasi yaitu $26,21 \%$.

Keadaan serupa juga terjadi pada variabel temu lapang yang memberikan pengaruh sebesar 45,02\% terhadap efektivitas diseminasi. Pengaruh temu lapang lebih besar dari pada pengaruh demplot terhadap efektivitas diseminasi namun lebih kecil dari variebel pelatihan. Pada pelaksanaan temu lapang melibatkan semua stakeholders dan nara sumber yang cukup mampu dalam memberikan penjelasana pada saat temu lapang, serta dihadiri oleh semua petani bawang putih tingkat kecamatan Tawangmangu. Hal ini yang menjadikan variabel temu lapang dapat berpengaruh lebih besar dari pada variabel demplot karena melibatkan semua petani. Dengan melihat hasil dari demplot yang meliputi produksitivitas dan umbi yang dihasilkan diharapkan dapat memeberikan keyakinan dan morivasi kepada petani bawang putih lainnya untuk dapat menerapkan teknologi budidaya bawang putih ramah lingkungan.

Diharapkan juga untuk penerapakan teknologi inovasi dapat diterapkan pada musim tanaman berikutnya baik petani kooperator maupun petani lainnya. Namun demikian dalam penerapan teknologi inovasi khususnya ramah lingkungan memerlukan dukungan dan kebijakan pemerintah setempat. Seperti yang disampaikan oleh Mardikanto (2010) menjelaskan bahwa dalam partisipasi, kebijakan pemerintah diharapkan memberikan kesempatan kepada masyarakat untuk berkembang oleh karena itu diperlukan ketegasan kebijakan dalam kaitannya untuk mencapai pembangunan baik tingkat nasional, regional maupun lokal. Selain itu, menurut Suharto (2008), menjelaskan fokus kebijakan pemerintah adalah pelayanan publik yang merupakan segala bentuk jasa pelayanan, baik bentuk barang maupun jasa publik yang prinsipnya menjadi tanggung jawab dalam mempertahankan dan meningkatkan kualitas hidup masyarakat.

Selain itu menurut Mardikanto (2009) yang menyebutkan diperlukan langkahlangkah nyata dan positif oleh pemerintah pusat maupun daerah dalam memberikan kemudahan pelayanan melalui kebijakannya, karena pemerintah daerah yang paling mengetahui kondisi, potensi dan kebutuhan masyarakat. Kemudahan kebijakan yang diberikan oleh pemerintah daerah merupakan peluang atau kesempatan bagi masyarakat khususnya kelompok tani untuk dapat mengembangkan potensi dirinya dalam rangka memperbaiki kualitas hidupnya. Hal ini senada 
dengan Slamet (1994) yang menyatakan bahwa syarat tumbuhnya partisipasi diperlukan kemauan, kemampuan, dan kesempatan untuk berpartisipasi.

Menurut Mardikanto (2010), adopsi inovasi terkait dengan pembangunan ada 3 (tiga) hal yang mendasar yaitu (1) memerlukan proses komunikasi yang terus menerus untuk mengenalkan, menjelaskan, mendidik, dan membantu masyarakat agar tahu, mau, dan mampu menerapkan inovasi; (2) merupakan proses pengambilan keputusan yang berkelanjutan dan tidak mengenal henti untuk memperhatikan, menerima, menghayati, memahami, dan menerapkan inovasi; dan (3) memerlukan kseiapan untuk melakukan perubahan-perubahan dalam penerapan inovasi.

Efektivitas menurut Slamet (2001) ekuivalen dengan keberhasilan yang dapat dilihat dari pencapaian tujuan. Tujuan dari diseminasi ini adalah tersampaikannya inovasi teknologi budidaya bawang putih ramah lingkungan. Pelaksanaan diseminasi menunjukkan keberhasilan dalam penyampaian inovasi teknologi, hal ini dapat dilihat berdasarkan penilaian dari responden terhadap tingkat efektivitas diseminasi sebesar $90 \%$.

\section{KESIMPULAN DAN SARAN}

\section{Kesimpulan}

Dari hasil analisa baik secara
deskriptif maupun secara statistik untuk
mengetahui efektivitas diseminasi teknologi
budidaya bawang putih ramah lingkungan di

Dari hasil analisa baik secara budidaya bawang putih ramah lingkungan di
Kabupaten Karanganyar, maka dapat disimpulkan sebagai berikut :

1. Secara deskriptif dengan melihat persepsi petani mengenai ektiktivitas diseminasi adalah 27 petani menialai bahwa pelaksanaan diseminasi efektif dengan nilai $90 \%$ telah dapat menyampaikan teknologi budidaya bawang putih ramah lingkungan di Kabupaten Karanganyar.

2. Menjawab hipotesis yang ada didapatkan bahwa H1 diterima artinya dari masingmasing variabel bebas yaitu pelatihan, demplot, dan temul lapang, artinya bahwa ketiga metode yaitu pelatihan, demplot, dan temu lapang secara signifikan berpengaruh terhadap efektivitas diseminasi.

3. Besar pengaruh dari ketiga metode yaitu pelatihan, demplot, dan temu lapang masing - masing adalah $79,92 \%, 26,21 \%$, dan $45,02 \%$.

4. Besar pengaruh dari ketiga metode yaitu pelatihan, demplot, dan temu lapang secara bersama-sama terhadap efektivitas desiminasi adalah $89,5 \%$ sedangkan sisanya yaitu $10,49 \%$ dipengaruh oleh faktor atau variabel lain diluar ketiga metode tersebut.

\section{Saran}

1. Dari hasil analisa yang diperoleh bahwa ketiga meode yang paling kecil pengaruhnya yaitu variabel demplot yaitu $26,21 \%$, untuk dapat meningkatkan pengaruh pelaksanaan demplot terhadap efektivitas diseminasi, diperlukan pelaksanaan demplot yang lebih luas (scalling up), agar semua petani bawang 
putih dapat langsung menerapkan inovasi

teknologi dimaksud.

2. Perlu dilakukan tambahan atau dilengkapi dengan metode penyuluhan lainnya, mengingat masih ada 10,49\% merupakan pengaruh variabel/faktor lain di luar metode yang telah dilakukan, sehingga harapannya pelaksanaan diseminasi dapat lebih efektif.

\section{DAFTAR PUSTAKA}

Johnson, Richard, A \& Dean, W Wichern (2002). Applied Multivariate Statistical Analysis Fifth Edition. Pearson Education International. USA

Mardikanto. (2009). Sistim Penyuluhan Pertanian. Sebelas Maret University Press. Surakarta.

Mardikanto. (2009). Membangun Pertanian Modern. UNS Press kerjasama Lembaga Pengembangan Pendidikan (LPP) UNS. Surakarta.

Mardikanto. (2010). Metoda Penelitian dan Evaluasi Pemberdayaan Masyarakat. Program Studi Penyuluhan Pembangunan/Pemberdayaan

Masyarakat Program Pascasarjana UNS. Surakarta.

Mardikanto. (2010). Komunikasi Pembangunan. Program Studi Penyuluhan

Pembangunan/Pemberdayaan

Masyarakat Program Pascasarjana UNS. Surakarta.

Mardikanto. (2010). Konsep-Konsep Pemberdayaan Masyarakat. UNS Press kerjasama Fakultas Pertanian UNS. Surakarta.

Riduwan \& Engkos A.K. (2008). Cara Menggunakan dan Memaknai Analisis Jalur (Path Analysis). CV. Alfabeta. Bandung

Slamet, Margono. (2001). Kelompok, Organisasi dan Kepemimpinan. Program Studi Ilmu Penyuluhan
Pembangunan Sekolah Pascasarjana IPB. Bogor.

Slamet Y. (1994). Pembangunan Masyarakat Berwawasan Partisipasi. Sebelas Maret University Press. Surakarta.

Suharto, Edi. (2008). Kajian Penerapan Pelayanan Khusus (Service for Customers with Special Needs) pada Sektor Pelayanan Publik, disampaikan pada Focused Group Discussion (FGD) Lembaga Administrasi Negara. Bogor. 